\title{
Up-Regulation of IL-18 and IL-12 in the Ileum of Neonatal Rats with Necrotizing Enterocolitis
}

\author{
MELISSA D. HALPERN, HANA HOLUBEC, JESSICA A. DOMINGUEZ, \\ CATHERINE S. WILLIAMS, YOLANDA G. MEZA, DEBRA L. McWILLIAM, CLAIRE M. PAYNE, \\ ROBERT S. McCUSKEY, DAVID G. BESSELSEN, AND BOHUSLAV DVORAK \\ Department of Pediatrics and Steele Memorial Children's Research Center [M.D.H., J.A.D., C.S.W., \\ Y.G.M., D.L.M., B.D.], Department of Microbiology and Immunology [H.H., C.M.P.], Department of \\ University Animal Care [D.G.B.], and Department of Cell Biology and Anatomy [R.S.M., B.D.],
}

University of Arizona, Tucson, Arizona, U.S.A.

\begin{abstract}
Necrotizing enterocolitis (NEC) is a common and devastating gastrointestinal disease of premature infants. Because the proinflammatory cytokines IL-18, IL-12, and interferon (IFN)- $\gamma$ have been implicated in other diseases of the small intestine, we hypothesized that these cytokines would play an important role in NEC pathogenesis. NEC was induced in newborn rats via enteral feeding with rat milk substitute and asphyxia and cold stress (RMS). Dam-fed, asphyxia- and cold-stressed littermates were used as controls (DF). After $96 \mathrm{~h}$, the distal ileum was removed from all animals and processed to determine expression and localization of IL-18, IL-12, and IFN- $\gamma$ using real-time reverse transcriptase PCR and immunohistology. IL-18 and IL-12 mRNA from the RMS group were increased ( $p \leq 0.05$ ) compared with DF controls, and there was a correlation between increasing IL-18 and IL-12 mRNA levels and progression of tissue damage ( $r=0.629$ and 0.588 , respectively; $p \leq 0.05$ ). Immunohistology revealed IL-18 in the cytoplasm of villi and crypt enterocytes and IL-12-positive monocytes/macrophages
\end{abstract}

\section{ABSTRACT}

were increased with disease progression $(r=0.503, p \leq 0.05)$. No differences in the number of IFN- $\gamma$-positive cells were observed between groups. These data demonstrate up-regulation of IL-18 and IL-12 in experimental NEC and a correlation between production of these proinflammatory cytokines and progression of tissue damage. (Pediatr Res 51: 733-739, 2002)

DF, dam fed

\section{Abbreviations}

IEC, intestinal epithelial cells

IFN- $\boldsymbol{\gamma}$, interferon- $\gamma$

LP, lamina propria

LPMC, lamina propria monocytes/macrophages

MC, monocytes/macrophages

NEC, necrotizing enterocolitis

NLPMC, non-lamina propria monocytes/macrophages

RT-PCR, reverse transcriptase PCR

RMS, rat milk substitute
NEC is the most common gastrointestinal disease of premature infants (1). Its etiology, however, remains elusive (2). It has been suggested that the major risk factors for NECprematurity, formula feeding, intestinal ischemia/hypoxia, and bacterial colonization - promote an inflammatory cascade that results in the pathology associated with this disease $(3,4)$. The development of animal models has been vital to the understanding of NEC (5). The neonatal rat model, where NEC is induced in newborn rats by enteral feeding of artificial formula

Received October 2, 2001; accepted January 21, 2002.

Correspondence: Melissa Halpern, PhD, Department of Pediatrics, University of Arizona, 1501 N. Campbell Ave, P.O. Box 245073, Tucson, AZ 85724-5073, U.S.A.; e-mail: mhalpern@peds.arizona.edu. Reprints: Bohuslav Dvorak, PhD, Department of Pediatrics, University of Arizona, 1501 N. Campbell Ave, P.O. Box 245073, Tucson, AZ 85724 5073, U.S.A.; e-mail: dvorakb@peds.arizona.edu

Supported by grants HD26013 and HD39657 (to B.D.) from the National Institute of Child Health and Human Development.

DOI: 10.1023/01.PDR.0000017480.64723.56 coupled with asphyxia and cold stress, is an established model for study of this disease $(6-11)$.

The intestinal environment is capable of producing an array of cytokines important in the development and control of inflammatory responses $(12,13)$. Among these, proinflammatory IL-18 (14-17), IL-12 (18-20), and IFN- $\gamma(21,22)$ have been implicated in inflammatory diseases of the small intestine. Individually, IL-18 and IL-12 can induce small amounts of IFN- $\gamma$ from T, natural killer (NK), and B cells. Together, IL-18 and IL-12 can work synergistically to induce greater quantities of IFN- $\gamma$ from these immunocompetent cells, and IL-18 and IL-12 can induce intestinal inflammation in the presence of IFN- $\gamma$ in mice (23). Both IL-18 and IL-12 are produced by $\mathrm{MC}$, however, IL-18 is produced by IEC as well $(12,24-26)$.

Cytokine profiles in NEC are poorly defined and sometimes contradictory. IFN- $\gamma$ mRNA showed a slight trend toward up-regulation in rats with experimental NEC (10) and was increased in infants with $\operatorname{NEC}(27,28)$. IL-12 mRNA was 
decreased in experimental NEC (10). Although IL-18 has not previously been studied in NEC, its constitutive production by murine fetal and adult IEC (25) and increased production in human epithelial cell lines subjected to hyperosmotic stress (29) suggest its potential as a mediator of tissue damage in NEC.

The goals of this study were to evaluate histologic localization and expression of IL-18, IL-12, and IFN- $\gamma$ in experimental NEC and determine the changes in cytokine production during the development of this disease. To achieve this aim, IL-18, IL-12, and IFN- $\gamma$ were evaluated in distal ileum of neonatal rats enterally fed artificial formula to induce experimental NEC using real-time RT-PCR and immunohistology.

\section{METHODS}

Animal model and diets. This protocol was approved by the Animal Care and Use Committee of the University of Arizona (A-324801-95081). Neonatal Sprague-Dawley rats (Charles River Laboratories, Wilmington, MA, U.S.A.) originating from 12 separate litters were used in four different experiments. Newborn rats were collected immediately after birth to prevent suckling of maternal milk. Animals were assigned to one of two experimental groups based on randomized weight: artificially fed with RMS (30), or DF. Pups from both experimental groups were stressed twice daily with asphyxia (breathing $100 \%$ nitrogen gas for $60 \mathrm{~s})$ followed by cold $\left(4^{\circ} \mathrm{C}\right.$ for $\left.10 \mathrm{~min}\right)$ to induce experimental NEC $(7,31)$. RMS pups were hand fed

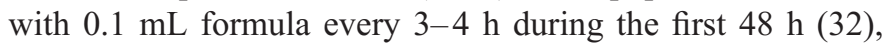
then this method was replaced with mechanized artificial feeding for an additional $48 \mathrm{~h}$ (30). Animals that developed signs of imminent death before $96 \mathrm{~h}$ were killed and tissues from these animals were included in this study. After 96 h, all surviving animals were terminated via decapitation.

NEC evaluation. After termination, the gastrointestinal tract was carefully removed and the small intestine was visually evaluated for typical signs of NEC (intestinal discoloration, intestinal hemorrhage, ileal distention, and/or ileal stenosis). A 2 -cm section of distal ileum proximal to the ileocecal valve from each animal was fixed overnight in $70 \%$ ethanol, paraffinembedded, sectioned at 4-6 $\mu \mathrm{m}$, and stained with hematoxylin and eosin for histologic evaluation of NEC. Histologic changes in the ileum were scored by a blinded evaluator and graded as follows: $0=$ normal, no damage; $1=$ slight submucosal and/or lamina propria separation; 2 = moderate separation of submucosa and/or lamina propria, and/or edema in submucosal and muscular layers; 3 = severe separation of submucosa and/or lamina propria, and/or severe edema in submucosa and muscular layers, region villous sloughing; $4=$ loss of villi with necrosis (Fig. 1).

$\boldsymbol{R N A}$ preparation. Total RNA was isolated from ileal tissue using the RNeasy Mini Kit (QIAGEN, Valencia, CA, U.S.A.) as described in the manufacturer's protocol. All samples were incubated with RNase-free DNase (20 U per reaction) for 10 min at $37^{\circ} \mathrm{C}$ to eliminate DNA contamination. RNA concentration was quantified by UV spectrophotometry at $260 \mathrm{~nm}$ and the purity was determined by the $\mathrm{A}_{260} / \mathrm{A}_{280}$ ratio (SPECTRAmax PLUS, Molecular Devices, Sunnyvale, CA, U.S.A.). The integrity of RNA was verified by electrophoresis on a $1.2 \%$ agarose gel containing formaldehyde $(2.2 \mathrm{M})$ and ethidium bromide in $1 \times$ MOPS buffer [40 mM MOPS (pH 7.0), $10 \mathrm{mM}$ sodium acetate, and $1 \mathrm{mM}$ EDTA (pH 8.0)].

Real time RT-PCR. Real-time RT-PCR assays were performed to specifically quantify rat IL-18, IL-12, and IFN- $\gamma$ steady-state mRNA levels. Single-stranded cDNA was reverse transcribed from $1 \mu \mathrm{g}$ of total RNA in a $10-\mu \mathrm{L}$ reaction mixture, as previously described in detail (33). The amounts of total RNA used in the reverse transcription reactions were calculated from the absorbency at $260 \mathrm{~nm}$, and verified by densitometry of the $28 \mathrm{~S}$ ribosomal RNA band separated on denaturing agarose gels (by Gel Doc 1000 Documentation System with Molecular Analyst/PC software, Bio-Rad, Hercules, CA, U.S.A.). Real-time PCR amplification $(34,35)$ was performed using rat IL-18, IL-12, and IFN- $\gamma$ TaqMan PreDeveloped Assay Reagents (Applied Biosystems, Foster City, CA, U.S.A.), as described in the manufacturer's protocol. Samples were subjected to 40 cycles of amplification at $95^{\circ}$ for $15 \mathrm{~s}$ followed by $1 \mathrm{~min}$ at $60^{\circ}$ using a GeneAmp 5700 Sequence Detection System (Applied Biosystems), according to the manufacturer's instructions. Water controls were included to ensure specificity. Relative quantification was used to determine the changes in steady-state mRNA levels between samples. Recently, Bustin (36) has clearly shown significant limitations and inaccuracies in using housekeeping genes such as $\beta$-actin or glyceraldehyde-3-phosphate dehydrogenase to normalize mRNA values. Therefore, we used relative quantification of steady-state mRNA levels between experimental groups and all mRNA measurements were calculated on the basis of total RNA concentration (36). Separate standard curves for IL-18, IL-12, and IFN- $\gamma$ were generated from serial dilutions of nonexperimental intestinal total RNA (from 1 to 1000 ng per reverse transcription reaction). Real-time monitoring of fluorescent emission from cleavage of sequencespecific probes by the nuclease activity of Taq polymerase allowed definition of the threshold cycle during the exponential phase of amplification. Data were expressed as the fold induction of gene expression in the RMS group compared with that in the DF group.

Immunohistology. Using the same tissue processed as described for staining with hematoxylin and eosin, serial sections were deparaffinized in three changes of xylene and rehydrated in a graded series of ethanol dilutions. Antigen unmasking was performed using $0.05 \%$ saponin (Sigma Chemical, St. Louis, MO, U.S.A.) for $30 \mathrm{~min}$, followed by blocking of endogenous peroxidase using $0.1 \%$ hydrogen peroxide for an additional 30 min. Sections were blocked with $1.5 \%$ rabbit serum (Vector Laboratories, Burlingame, CA, U.S.A.) for $30 \mathrm{~min}$, then incubated with the following polyclonal goat anti-rat antibodies (Santa Cruz Biotechnology, Santa Cruz, CA, U.S.A.): $5 \mu \mathrm{g} / \mathrm{mL}$ IFN- $\gamma, 5 \mu \mathrm{g} / \mathrm{mL}$ IL-12, or $2 \mu \mathrm{g} / \mathrm{mL}$ IL-18 for an additional 30 min. After three PBS washes, biotinylated rabbit anti-goat secondary antibody (Vector Laboratories) was applied for 30 min, followed by three PBS washes, then Vectastain Elite ABC reagent (Vector Laboratories) for $30 \mathrm{~min}$. Diaminobenzidine was used as the substrate and sections were counterstained with hematoxylin, dehydrated, and cover-slipped using Cytoseal 


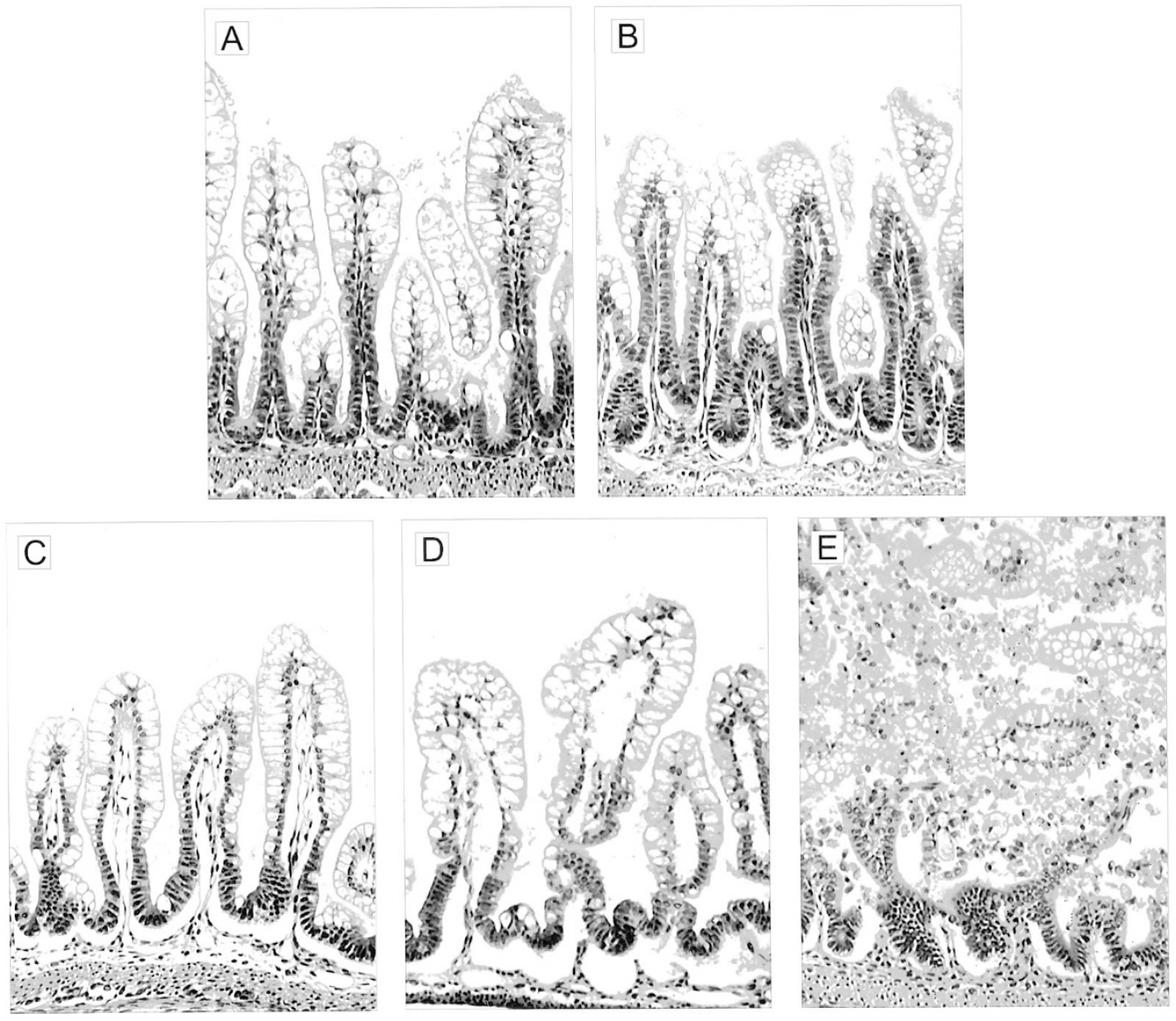

Figure 1. Histologic scoring of distal ileum of neonatal rats. Neonatal rat ileum stained with hematoxylin and eosin showing representative sections for each morphologic grading score. $(A)$ Normal ileum, NEC score 0 . Note there is no separation in the submucosa or LP. (B) NEC score 1, slight submucosal and LP separation. (C) NEC score 2, moderate separation of the submucosa and LP with edema of the submucosa. $(D)$ NEC score 3 , severe separation of the submucosa and LP. $(E)$ NEC score 4, necrosis and loss of villi structure. Magnification $\times 200$.

XYL (Stephens Scientific, Kalamazoo, MI, U.S.A.) (37). Control sections were treated with the same procedure, except they were incubated with $5 \mu \mathrm{g} / \mathrm{mL}$ goat Ig (Sigma Chemical) instead of the specific cytokine antibodies. No signal was observed in the controls. Sections from the DF and RMS groups were simultaneously stained for a specific cytokine so that comparisons of staining intensities between groups could be assessed. Stained slides were evaluated by a blinded observer. Sections from animals with a NEC score of 4 were not included in analyses because of the lack of intact tissue to evaluate.

Enumeration of MC and T cells. Sections of distal ileum were processed as described above with the following changes: Sections were blocked with $1.5 \%$ horse serum for $30 \mathrm{~min}$, followed by $30 \mathrm{~min}$ incubation with either $2.0 \mu \mathrm{g} / \mathrm{mL}$ monoclonal mouse anti-rat ED1 (Serotec, Raleigh, NC, U.S.A.) to stain for MC surface markers or $5.0 \mu \mathrm{g} / \mathrm{mL}$ monoclonal mouse anti-rat CD3 (BD PharMingen, San Diego, CA, U.S.A.) to stain for $\mathrm{T}$ cells. Isotype-matched mouse IgG1 and IgM antibodies were used as negative controls for ED1 and CD3, respectively. After three PBS washes, slides were incubated with biotinylated horse anti-mouse secondary antibody for 30 $\mathrm{min}$. Positively stained $\mathrm{MC}$ and $\mathrm{T}$ cells were enumerated from 20 intact villi and the adjacent submucosal regions from a section of tissue most representative of the histologic NEC score of the tissue sample. Ethanol-fixed sections of rat spleen were used as a positive control for MC and T cells (results not shown). No staining was observed in control slides.

Statistics. Statistical analyses between DF and RMS groups were performed using ANOVA followed by Fisher PLSD. Correlation analyses related to degree of tissue damage were performed using Spearman rank correlation. All statistical analyses were accomplished using the statistical program StatView for Macintosh computers (Abacus Concepts, Berkeley, CA, U.S.A.). All numerical data are expressed as mean \pm SEM.

\section{RESULTS}

Incidence and severity of NEC in RMS-fed animals. Tissues with histologic scores $\geq 2$ were designated positive for NEC. In the RMS group $(n=17), 82 \%$ showed pathologic changes in ileal structure characterized as moderate, severe, or full necrosis versus $0 \%$ in the DF group $(n=15)$. The degree of ileal damage was also significantly increased in RMS versus the DF animals, with mean NEC scores of $2.6 \pm 1.0$ and 0.41 \pm 0.2 , respectively $(p \leq 0.05)$. 
Ileal cytokine mRNA levels. To evaluate changes in gene expression for IL-18, IL-12, and IFN- $\gamma$, steady-state mRNA levels from ileal tissue were measured using real-time RTPCR. Ileal IL-18 and IL-12 mRNA from the RMS group were statistically significantly increased compared with the DF group. IFN- $\gamma$ mRNA levels were similar in both DF and RMS groups (Fig. 2). Correlation analyses showed a positive relationship between increasing IL-18 and IL-12 mRNA levels and progression of tissue damage $(r=0.629$ and 0.588 , respectively; $p \leq 0.05$ ).

Localization of IL-18. Immunohistologic staining revealed IL-18 was increased with progression of disease. In DF animals (Fig. 3A), IL-18 was localized predominantly in isolated IEC, with some staining observed in the LP. In RMS animals with NEC scores between 1 and 2 (Fig. 3B), the IL-18 staining pattern had features of the DF group (isolated IEC and LP staining) coupled with cytoplasmic staining of regional villi and crypt enterocytes. In RMS animals with NEC scores between 2 and 3, IL-18 was found throughout the cytoplasm of villi and crypt enterocytes, often with higher intensity staining on the apical membranes of the villi enterocytes (Fig. 3C). No staining was observed in submucosal layers for any treatment group. Enumeration of individually stained cells between groups was not performed because of the overall cytoplasmic staining that predominated in the RMS group.

Localization of IL-12 and IFN- $\gamma$. IL-12 was detected in individually stained MC in the submucosa and LP in DF and RMS animals. Enumeration from 20 villi and adjacent submucosal regions revealed a statistically significant increase of IL-12-positive cells in RMS versus DF animals (Fig. 4). In addition, statistical analysis showed a correlation between the number of IL-12-positive cells and tissue damage ( $r=0.503$, $p \leq 0.05)$. IFN- $\gamma$ was observed sporadically in T cells in all groups (2-4 positive cells/20 villi). There were no statistical differences in the number of IFN- $\gamma$-positive cells between DF and RMS groups.

Enumeration of macrophages and $\boldsymbol{T}$ cells. Because IL-18 can be produced by IEC as well as immune cells, we investigated the infiltration of $\mathrm{MC}$ and $\mathrm{T}$ cells in DF and RMS animals (Table 1). All MC were counted and divided into two groups: LPMC and NLPMC found elsewhere in the villi, crypts, and/or submucosa. In all experimental groups, MC were the predominant immunologic cell type. However, the majority of MC were negative for IL-18, and those LPMC that were positively stained were restricted to the upper half of the villi. The number of LPMC in the RMS group was statistically significantly increased compared with DF animals. There was, however, no correlation between the number of LPMC and degree of tissue damage. In addition, there was no difference between numbers of NLPMC or T cells between groups.

\section{DISCUSSION}

The present study demonstrates increased production of proinflammatory cytokines IL-18 and IL-12 in the small intestine of neonatal rats with NEC. Moreover, increased IL-18 and IL-12 are correlated with progression of tissue damage. Although previous studies have shown enhanced IL-18 produc-
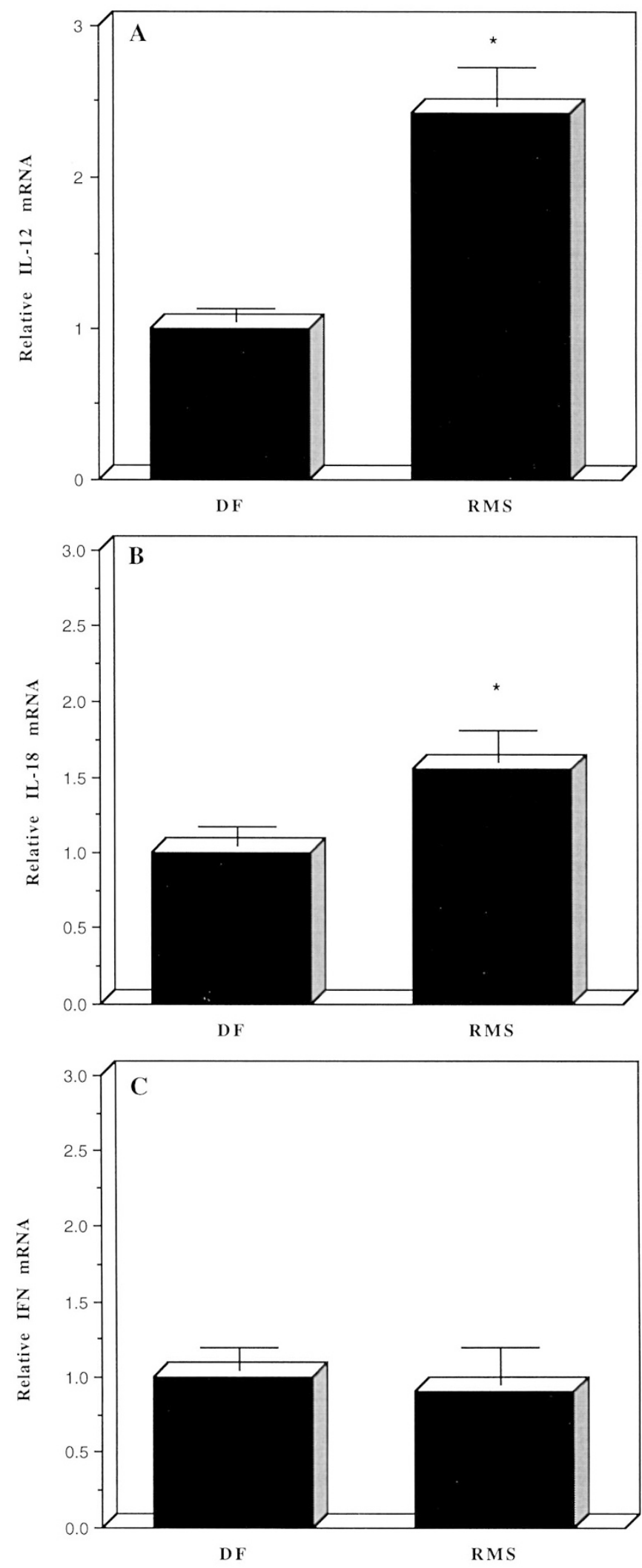

Figure 2. IL-12 $(A)$ and IL-18 $(B)$ but not IFN- $\gamma(C)$ mRNA levels are increased in distal ileum of neonatal rats with NEC. RNA was extracted from ileal tissue from DF $(n=10)$ and RMS $(n=10)$ groups, and relative mRNA levels were compared for each cytokine using real-time RT-PCR. For each cytokine, the mean steady-state mRNA level for the DF group was assigned a value of 1.0 and the mean mRNA from the RMS group was determined relative to this number. ${ }^{*}$ Statistically significant $v s \mathrm{DF}, p \leq 0.05$. 

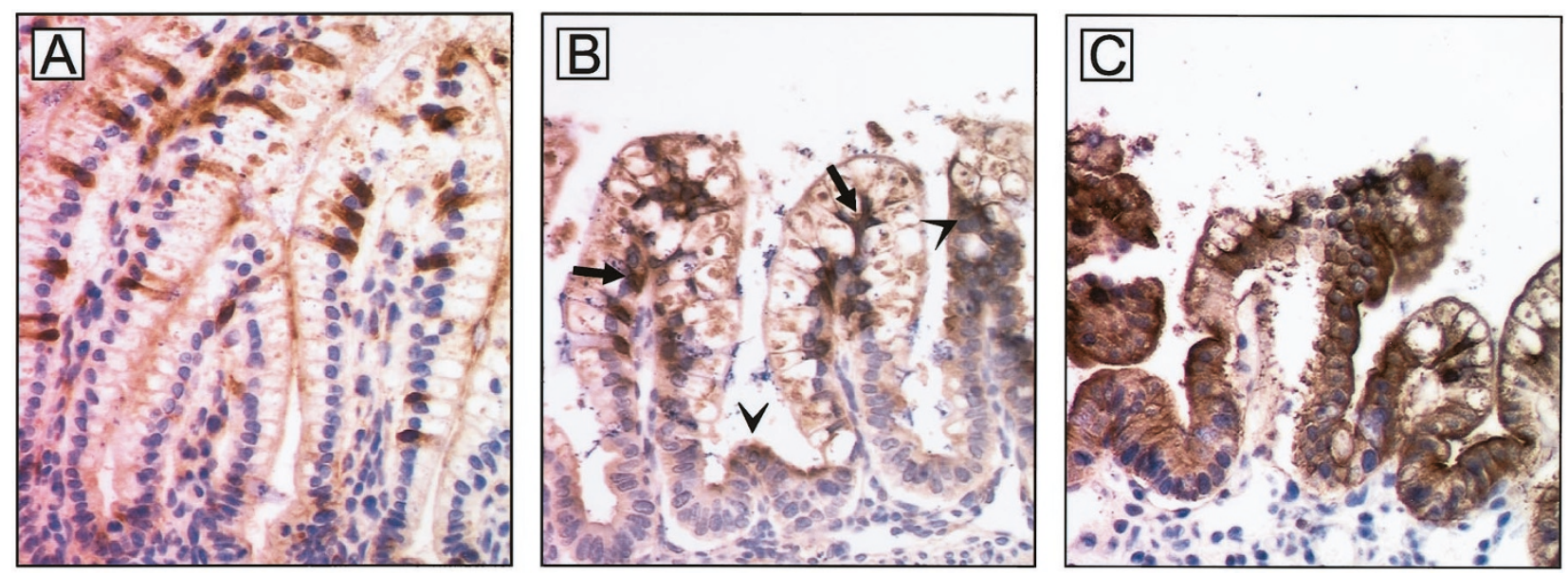

Figure 3. IL-18 localization in distal ileum of neonatal rats increases with progression of disease. Representative slides for $(A)$ DF group, IL-18 localized predominately in IEC and LP; $(B)$ RMS group, histologic NEC score of 2, IL-18 localization in IEC and LP staining (arrows) found in DF animals coupled with cytoplasmic and apical membrane staining (arrowheads); and (C) RMS group, histologic NEC score of 3, IL-18 further increased and found in the cytoplasm of the villi and crypt enterocytes and on the apical membrane of the villi enterocytes. Magnification $\times 200$.

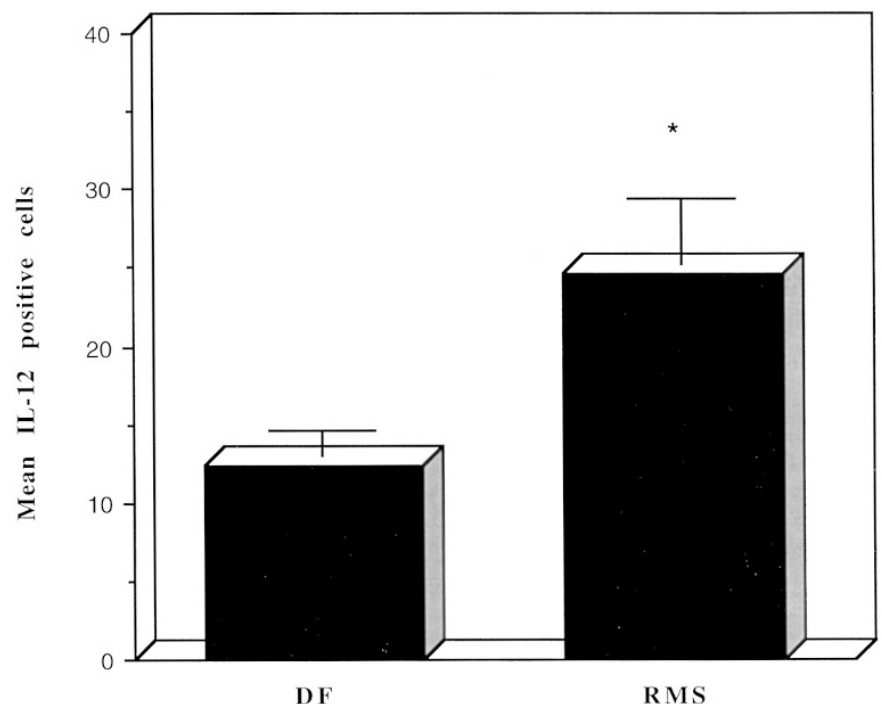

Figure 4. IL-12-positive cells are increased in neonatal rats with NEC. Positively stained cells from DF $(n=8)$ and RMS $(n=12)$ groups were counted from 20 intact villi and the adjacent submucosal regions. *Statistically significant $v$ DF, $p \leq 0.05$.

tion in Crohn's disease $(16,17)$, this study is the first to describe gene expression and histologic localization of IL-18 and their correlation to tissue damage in NEC.

Previous studies have shown that, in the presence of IL-12, IL-18 induces IFN- $\gamma$ production from T and NK cells (38-40). However, the abundant IL-18 levels in animals with NEC did not correspond to greater IFN- $\gamma$ production. Although IL-18 and IL-12 are normally potent inducers of IFN- $\gamma$, this cytokine was detected infrequently in all experimental groups. The paucity of mature $\mathrm{T}$ and NK cells in the 4-d-old neonatal intestine likely accounts for the low incidence of IFN- $\gamma$. Chikano et al. (23) reported that administration of exogenous IL-18 and IL-12 induced intestinal inflammation in adult mice in an IFN- $\gamma$-dependent manner. In this study, we show intestinal damage in a setting of increased IL-18 and IL-12 without increased IFN- $\gamma$. One explanation for this apparent paradox is
Table 1. Enumeration of LPMC, NLPMC, and T cells from distal ileum of neonatal rats

\begin{tabular}{lcc}
\hline & $\begin{array}{c}\text { DF } \\
(n=10)\end{array}$ & $\begin{array}{c}\text { RMS } \\
(n=12)\end{array}$ \\
\hline Total MC & $67.2 \pm 4.0$ & $83.4 \pm 6.7$ \\
LPMC & $32.0 \pm 3.2$ & $58.7 \pm 4.9^{*}$ \\
NLPMC & $35.2 \pm 3.0$ & $24.6 \pm 2.9$ \\
Total CD3 (T) cells & $11.4 \pm 2.3$ & $16.7 \pm 3.0$ \\
\hline
\end{tabular}

MC from 20 villi and adjacent submucosal regions were counted and divided into two groups: LPMC and NLPMC. Data are expressed as mean \pm SE.

* Statistically significant $v s \mathrm{DF}, p \leq 0.05$.

that, although IFN- $\gamma$ levels do not appear to be increased during NEC development, this cytokine is produced and may provide the required co-signals to induce tissue destruction. However, Simpson et al. (41) reported that IL-12-dependent colitis may not require IFN- $\gamma$, demonstrating an uncertainty as to the requirement for IFN- $\gamma$ in intestinal pathology. Additionally, it is well documented that the microenvironment of the neonatal intestine differs significantly from more mature intestine (42-44). It is likely, therefore, that immunoregulatory features of the neonatal gastric mucosa differ from that of adults, and these differences could account for our finding of tissue damage without increased IFN- $\gamma$ in the small intestine.

Published reports from other laboratories indicated that IFN- $\gamma$ mRNA was increased in both neonatal rats and infants with $\operatorname{NEC}(10,27,28)$, and IL-12 mRNA was decreased in experimental NEC (10). In the present work, we showed increased IL-12 mRNA with no change for IFN- $\gamma$ mRNA in animals with NEC. We used real-time RT-PCR as opposed to the conventional RT-PCR methods used by other laboratories $(10,27,28)$. This innovative method provides a more accurate and highly reproducible quantification of mRNA compared with conventional RT-PCR methodologies. As an additional confirmation, we were able to show that the number of cells positive for both cytokines at the protein level mimicked our mRNA data. 
IL-18 has been implicated in inflammatory disorders including inflammatory bowel diseases $(45,46)$. IL-18 has important proinflammatory effects on many types of immune cells (47), and shares functions similar to those reported for IL-12, including stimulation of T-cell proliferation, enhancement of the lytic activity of NK cells, and induction of IFN- $\gamma(48)$. The mucosal immune system mainly consists of LP lymphocytes, functionally and phenotypically similar to peripheral lymphocytes (49), and intraepithelial lymphocytes, similar to thymocytes (50). However, IEC, in addition to their absorptive, secretory, and barrier functions, have an immunologic role as well (43). Because the immune functions of neonatal intestine are not well developed, the production of IL-18 by both MC and $\operatorname{IEC}(25,45)$ makes it a prime candidate to mediate tissue damage in NEC.

Although the number of MC infiltrating into the LP of animals with NEC was increased compared with DF animals, there was no correlation between numbers of LPMC and degree of tissue damage. These data suggest that the increased IL-18, which can be produced by both MC and IEC, may be produced predominantly by IEC. These results may also indicate that the increased production of both IL-18 and IL-12 by $\mathrm{MC}$ is not dependent on total numbers of cells, but rather by a state of increased activation of these cells.

In humans, NEC is a disease primarily of premature, formula-fed infants and occurs with less frequency and severity when babies are fed human breast milk $(3,51-54)$. Among the bioactive components found in breast milk that are lacking in commercial infant formula, cortisol, lysozyme, and IL-10 have potential anti-inflammatory effects (55). We speculate that the ability of neonatal gastric mucosa to produce large quantities of IL-18 may be down-regulated by the immunomodulatory agents found in breast milk. In formula-fed infants, the combination of an immature intestine coupled with a lack of the anti-inflammatory components of milk may allow the production of IL-18 to escalate to pathologic proportions.

The results of this study suggest a role for IL-18 and IL-12 in the pathogenesis of NEC. These data have implications for understanding both the development of and future therapeutic approaches to this disease.

\section{REFERENCES}

1. Neu J 1996 Necrotizing enterocolitis: the search for a unifying pathogenic theory leading to prevention. Pediatr Clin North Am 43:409-432

2. Schanler RJ 2000 Overview: the clinical perspective. J Nutr 130:417S-419S

3. Caplan MS, MacKendrick W 1993 Necrotizing enterocolitis: a review of pathogenetic mechanisms and implications for prevention. Pediatr Pathol 13:357-369

4. Nanthakumar NN, Fusunyan RD, Sanderson I, Walker WA 2000 Inflammation in the developing human intestine: a possible pathophysiologic contribution to necrotizing enterocolitis. Proc Natl Acad Sci U S A 97:6043-6048

5. Crissinger KD 1995 Animal models of necrotizing enterocolitis. J Pediatr Gastroenterol Nutr 20:17-22

6. Caplan MS, Miller-Catchpole R, Kaup S, Russell T, Lickerman M, Amer M, Xiao Y, Thomson Jr R 1999 Bifidobacterial supplementation reduces the incidence of necrotizing enterocolitis in a neonatal rat model. Gastroenterology 117:577-583

7. Caplan MS, Hedlund E, Adler L, Hsueh W 1994 Role of asphyxia and feeding in a neonatal rat model of necrotizing enterocolitis. Pediatr Pathol 14:1017-1028

8. Caplan MS, Russel T, Xiao Y, Amer M, Kaup S, Jilling T 2001 Effect of polyunsaturated fatty acid (PUFA) supplementation on intestinal inflammation and necrotizing enterocolitis (NEC) in a neonatal rat model. Pediatr Res 49:647-652

9. Schiffrin EJ, Carter EA, Walker WA, Frieberg E, Benjamin J, Israel EJ 1993 Influence of prenatal corticosteroids on bacterial colonization in the newborn rat. J Pediatr Gastroenterol Nutr 17:271-275
10. Nadler EP, Dickinson E, Knisely A, Zhang XR, Boyle P, Beer-Stolz D, Watkins SC, Ford HR 2000 Expression of inducible nitric oxide synthase and interleukin-12 in experimental necrotizing enterocolitis. J Surg Res 92:71-77

11. Dvorak BH, Halpern MD, Holubec H, Williams CS, McWilliam D, Dominguez JA, Stepankova R, Payne CM, McCuskey RS 2002 Epidermal growth factor reduces the development of necrotizing enterocolitis in a neonatal rat model. Am J Physiol 282:156-164

12. Jung HC, Eckmann L, Yang SK, Panja A, Fierer J, Morzycka-Wroblewska E, Kagnoff MF 1995 A distinct array of proinflammatory cytokines is expressed in human colon epithelial cells in response to bacterial invasion. J Clin Invest 95:55-65

13. MacDermott RP 1996 Alterations of the mucosal immune system in inflammatory bowel disease. J Gastroenterol 31:907-916

14. Kanai T, Watanabe M, Okazawa A, Nakamaru K, Okamoto M, Naganuma M, Ishii $\mathrm{H}$, Ikeda M, Kurimoto M, Hibi T 2000 Interleukin 18 is a potent proliferative factor for intestinal mucosal lymphocytes in Crohn's disease. Gastroenterology 119:15141523

15. Kanai T, Watanabe M, Okazawa A, Sato T, Hibi T 2001 Interleukin-18 and Crohn's disease. Digestion 63:37-42

16. Monteleone G, Trapasso F, Parrello T, Biancone L, Stella A, Iuliano R, Luzza F, Fusco A, Pallone F 1999 Bioactive IL-18 expression is up-regulated in Crohn's disease. J Immunol 163:143-147

17. Pizarro TT, Michie MH, Bentz M, Woraratanadharm J, Smith Jr MF, Foley E, Moskaluk CA, Bickston SJ, Cominelli F 1999 IL-18, a novel immunoregulatory cytokine, is up-regulated in Crohn's disease: expression and localization in intestinal mucosal cells. J Immunol 162:6829-6835

18. Monteleone G, Biancone L, Marasco R, Morrone G, Marasco O, Luzza F, Pallone F 1997 Interleukin 12 is expressed and actively released by Crohn's disease intestinal lamina propria mononuclear cells. Gastroenterology 112:1169-1178

19. Monteleone G, MacDonald TT, Wathen NC, Pallone F, Pender SL 1999 Enhancing lamina propria Th1 cell responses with interleukin 12 produces severe tissue injury. Gastroenterology 117:1069-1077

20. Parrello T, Monteleone G, Cucchiara S, Monteleone I, Sebkova L, Doldo P, Luzza F, Pallone F 2000 Up-regulation of the IL-12 receptor beta 2 chain in Crohn's disease. J Immunol 165:7234-7239

21. Bregenholt S, Brimnes J, Nissen MH, Claesson MH 1999 In vitro activated $\mathrm{CD}^{+}{ }^{+} \mathrm{T}$ cells from interferon-gamma (IFN-gamma)- deficient mice induce intestinal inflammation in immunodeficient hosts. Clin Exp Immunol 118:228-234

22. Camoglio L, Te Velde AA, Tigges AJ, Das PK, Van Deventer SJ 1998 Altered expression of interferon-gamma and interleukin-4 in inflammatory bowel disease. Inflamm Bowel Dis 4:285-290

23. Chikano S, Sawada K, Shimoyama T, Kashiwamura SI, Sugihara A, Sekikawa K, Terada N, Nakanishi K, Okamura H 2000 IL-18 and IL-12 induce intestinal inflammation and fatty liver in mice in an IFN-gamma dependent manner. Gut 47:779-786

24. Shirota K, LeDuy L, Yuan SY, Jothy S 1990 Interleukin-6 and its receptor are expressed in human intestinal epithelial cells. Virchows Arch B Cell Pathol Incl Mol Pathol 58:303-308

25. Takeuchi M, Nishizaki Y, Sano O, Ohta T, Ikeda M, Kurimoto M 1997 Immunohistochemical and immuno-electron-microscopic detection of interferon-gammainducing factor ("interleukin-18") in mouse intestinal epithelial cells. Cell Tissue Res 289:499-503

26. Bodger K, Bromelow K, Wyatt JI, Heatly RV 2001 Interleukin 10 in Helicobacter pylori associated gastritis: immunohistochemical localisation and in vitro effects on cytokine production. J Clin Pathol 54:285-292

27. Ford H, Watkins S, Reblock K, Rowe M 1997 The role of inflammatory cytokines and nitric oxide in the pathogenesis of necrotizing enterocolitis. J Pediatr Surg 32:275 282

28. Ford HR, Sorrells DL, Knisely AS 1996 Inflammatory cytokines, nitric oxide, and necrotizing enterocolitis. Semin Pediatr Surg 5:155-159

29. Takeuchi M, Okura T, Mori T, Akita K, Ohta T, Ikeda M, Ikegami H, Kurimoto M 1999 Intracellular production of interleukin-18 in human epithelial-like cell lines is enhanced by hyperosmotic stress in vitro. Cell Tissue Res 297:467-473

30. Dvorak B, McWilliam DL, Williams CS, Dominguez JA, Machen NW, McCuskey RS, Philipps AF 2000 Artificial formula induces precocious maturation of the small intestine of artificially reared suckling rats. J Pediatr Gastroenterol Nutr 31:162-169

31. Barlow B, Santulli TV, Heird WC, Pitt J, Blanc WA, Schullinger JN 1974 An experimental study of acute neonatal enterocolitis - the importance of breast milk. J Pediatr Surg 9:587-595

32. Stepankova R, Dvorak B, Sterzl J, Trebichavsky I 1990 Effects of essential fatty acids deficiency in milk diets on the development of germ-free and conventional rats. Physiol Bohemoslov 39:135-146

33. Dvorak B, Kolinska J, McWilliam DL, Williams CS, Higdon T, Zakostelecka M, Koldovsky O 1998 The expression of epidermal growth factor and transforming growth factor-alpha mRNA in the small intestine of suckling rats: organ culture study. FEBS Lett 435:119-124

34. Brieland JK, Jackson C, Menzel F, Loebenberg D, Cacciapuoti A, Halpern J, Hurst S, Muchamuel T, Debets R, Kastelein R, Churakova T, Abrams J, Hare R, O'Garra A 2001 Cytokine networking in lungs of immunocompetent mice in response to inhaled Aspergillus fumigatus. Infect Immun 69:1554-1560

35. Gibson UE, Heid CA, Williams PM 1996 A novel method for real time quantitative RT-PCR. Genome Res 6:995-1001

36. Bustin SA 2000 Absolute quantification of mRNA using real-time reverse transcription polymerase chain reaction assays. J Mol Endocrinol 25:169-193

37. Whiteland JL, Nicholls SM, Shimeld C, Easty DL, Williams NA, Hill TJ 1995 Immunohistochemical detection of T-cell subsets and other leukocytes in paraffinembedded rat and mouse tissues with monoclonal antibodies. J Histochem Cytochem 43:313-320 
38. Ahn HJ, Maruo S, Tomura M, Mu J, Hamaoka T, Nakanishi K, Clark S, Kurimoto M, Okamura H, Fujiwara H 1997 A mechanism underlying synergy between IL-12 and IFNgamma-inducing factor in enhanced production of IFN-gamma. J Immunol 159:2125-2131

39. Micallef MJ, Ohtsuki T, Kohno K, Tanabe F, Ushio S, Namba M, Tanimoto T, Torigoe K, Fujii M, Ikeda M, Fukuda S, Kurimoto M 1996 Interferon-gamma-inducing factor enhances $\mathrm{T}$ helper 1 cytokine production by stimulated human $\mathrm{T}$ cells: synergism with interleukin-12 for interferon-gamma production. Eur J Immunol 26:1647-1651

40. Okamura H, Kashiwamura S, Tsutsui H, Yoshimoto T, Nakanishi K 1998 Regulation of interferon-gamma production by IL-12 and IL-18. Curr Opin Immunol 10:259-264

41. Simpson SJ, Shah S, Comiskey M, de Jong YP, Wang B, Mizoguchi E, Bhan AK, Terhorst C $1998 \mathrm{~T}$ cell-mediated pathology in two models of experimental colitis depends predominantly on the interleukin 12/signal transducer and activator of transcription (Stat)-4 pathway, but is not conditional on interferon gamma expression by T cells. J Exp Med 187:1225-1234

42. Insoft RM, Sanderson IR, Walker WA 1996 Development of immune function in the intestine and its role in neonatal diseases. Pediatr Clin North Am 43:551-571

43. Mannick E, Udall Jr JN 1996 Neonatal gastrointestinal mucosal immunity. Clin Perinatol 23:287-304

44. Sanderson IR 1999 The physicochemical environment of the neonatal intestine. Am J Clin Nutr 69:1028S-1034S

45. Dinarello CA 2000 Interleukin-18, a proinflammatory cytokine. Eur Cytokine Netw 11:483-486

46. Gracie JA, Forsey RJ, Chan WL, Gilmour A, Leung BP, Greer MR, Kennedy K, Carter R, Wei XQ, Xu D, Field M, Foulis A, Liew FY, McInnes IB 1999 A proinflammatory role for IL-18 in rheumatoid arthritis. J Clin Invest 104:1393-1401
47. Kohno K, Kataoka J, Ohtsuki T, Suemoto Y, Okamoto I, Usui M, Ikeda M, Kurimoto M 1997 IFN-gamma-inducing factor (IGIF) is a costimulatory factor on the activation of Th1 but not Th2 cells and exerts its effect independently of IL-12. J Immunol 158:1541-1550

48. Trinchieri G 1994 Interleukin-12: a cytokine produced by antigen-presenting cells with immunoregulatory functions in the generation of T-helper cells type 1 and cytotoxic lymphocytes. Blood 84:4008-4027

49. Guy-Grand D, Cerf-Bensussan N, Malissen B, Malassis-Seris M, Briottet C, Vassalli P 1991 Two gut intraepithelial CD8 ${ }^{+}$lymphocyte populations with different T cell receptors: a role for the gut epithelium in T cell differentiation. J Exp Med 173:471481

50. Poussier P, Julius M 1994 Thymus independent T cell development and selection in the intestinal epithelium. Annu Rev Immunol 12:521-553

51. Lucas A, Cole TJ 1990 Breast milk and neonatal necrotising enterocolitis. Lancet $336: 1519-1523$

52. Schanler RJ, Hurst NM, Lau C 1999 The use of human milk and breastfeeding in premature infants. Clin Perinatol 26:379-398, vii

53. Schanler RJ, Shulman RJ, Lau C 1999 Feeding strategies for premature infants: beneficial outcomes of feeding fortified human milk versus preterm formula. Pediatrics 103:1150-1157

54. Schanler RJ 1998 The role of human milk fortification for premature infants. Clin Perinatol 25:645-657, ix

55. Goldman AS 2000 Modulation of the gastrointestinal tract of infants by human milk. Interfaces and interactions. An evolutionary perspective. J Nutr 130:426S-431S 